University of Nebraska - Lincoln

DigitalCommons@University of Nebraska-Lincoln

Drought Mitigation Center Faculty Publications Drought -- National Drought Mitigation Center

$11-24-2012$

\title{
Agricultural Advisors: A Receptive Audience for Weather and Climate Information?
}

\author{
Linda Stalker Prokopy \\ Tonya Haigh \\ Amber Saylor Mase \\ Jim Angel \\ Chad Hart
}

See next page for additional authors

Follow this and additional works at: https://digitalcommons.unl.edu/droughtfacpub

Digitart of the Climate Commons, Environmental Indicators and Impact Assessment Commons, Epmmpnental Monitoring Commons, Hydrology Commons, Other Earth Sciences Commons, and the Weterekkesource Management Commons

Logo

This Article is brought to you for free and open access by the Drought -- National Drought Mitigation Center at DigitalCommons@University of Nebraska - Lincoln. It has been accepted for inclusion in Drought Mitigation Center Faculty Publications by an authorized administrator of DigitalCommons@University of Nebraska - Lincoln. 


\section{Authors}

Linda Stalker Prokopy, Tonya Haigh, Amber Saylor Mase, Jim Angel, Chad Hart, Cody Knutson, Maria Carmen Lemos, Yun Jia Lo, Jean McGuire, Lois Wright Morton, Jennifer Perron, Dennis Todey, and Melissa Widhalm 


\title{
Agricultural Advisors: A Receptive Audience for Weather and Climate Information?
}

\author{
Linda Stalker Prokopy, ${ }^{*}$ Tonya Haigh, ${ }^{+}$Amber SAylor Mase, $*$ Jim Angel, ${ }^{\#}$ Chad Hart $\stackrel{ }{\varrho}$ \\ Cody Knutson, ${ }^{+}$MARIA CARMEn Lemos, ${ }^{\&}$ Yun-JiA Lo, ${ }^{* *}$ JeAn MCGuire, ${ }^{@}$ Lois Wright Morton, ${ }^{@}$ \\ JenNifer Perron, ${ }^{\&}$ Dennis Todey,${ }^{++}$AND Melissa Widhalm* \\ * Purdue University, West Lafayette, Indiana \\ ${ }^{+}$National Drought Mitigation Center, University of Nebraska-Lincoln, Lincoln, Nebraska \\ \# Illinois State Water Survey, Prairie Research Institute, University of Illinois at Urbana-Champaign, Urbana, Illinois \\ ${ }^{\circledR}$ Iowa State University, Ames, Iowa \\ \& University of Michigan, Ann Arbor, Michigan \\ ** Michigan State University, East Lansing, Michigan \\ ${ }^{++}$South Dakota State University, Brookings, South Dakota
}

(Manuscript received 23 July 2012, in final form 24 November 2012)

\begin{abstract}
As the climate in the midwestern United States becomes increasingly variable because of global climate change, it is critical to provide tools to the agricultural community to ensure adaptability and profitability of agricultural cropping systems. When used by farmers and their advisors, agricultural decision support tools can reduce uncertainty and risks in the planning, operation, and management decisions of the farm enterprise. Agricultural advisors have historically played a key role in providing information and guidance in these decisions. However, little is known about what these advisors know or think about weather and climate information and their willingness to incorporate this type of information into their advice to farmers. In this exploratory study, a diverse set of professionals who advise corn growers, including government, nonprofit, for-profit, and agricultural extension personnel, were surveyed in four states in the midwestern Corn Belt. Results from the survey indicate that advisors are more influenced by current weather conditions and 1-7-day forecasts than longer-term climate outlooks. Advisors predominantly consider historical weather trends and/or forecasts in their advice to farmers on short-term operational decisions versus longer-term tactical and strategic decisions. The main conclusion from this analysis is that opportunities exist to further engage the advisor community on weather and climate issues and, through them, the farmers who are managing the land.
\end{abstract}

\section{Introduction}

Growing sufficient food, fuel, and fiber to meet the world's needs in a sustainable manner is dependent upon favorable weather conditions. The upper midwestern United States, commonly referred to as the Corn Belt, produces more than one-third of the global supply of corn (USDA NASS 2011; USDA FAS 2012). Short and long-term weather patterns affect agriculture in this region and are expected to become increasingly variable due to climate change (Karl et al. 2009).

Modern agriculture is an intensive operation that combines simultaneous and staged decisions, by season and across multiple years, about a large number of issues,

Corresponding author address: Linda Stalker Prokopy, Purdue University, 195 Marsteller Street, West Lafayette, IN 47907.

E-mail: lprokopy@purdue.edu including crop and seed selection, nutrient inputs (rate, timing, method, type), planting and harvesting timing and processes, crop insurance, equipment purchases, crop protection needs, and land management practices. Climate and weather information may impact agricultural decisions at multiple time scales. Farmers make short-term, operational decisions impacting field work in part based on current weather and meteorological forecasts, while tactical or strategic decisions (crop selection, equipment investments, or land purchases) may have a longer lead time and depend upon climatological information at some level (Hollinger 2009; Stone and Meinke 2006).

Because of the complexity and the variety of information and skills involved in decision making, farmers often rely on significant input from agricultural specialists. In the United States, there is a diverse group of agricultural advisors, ranging from agricultural extension staff 
working through land grant universities to government agencies (such as the state's Department of Agriculture, the Natural Resources Conservation Service, and soil and water conservation districts) to for-profit groups and individuals (such as seed and fertilizer salespeople, certified crop consultants, bankers, and lawyers) who could potentially broker and customize climate information to farmers.

A number of studies have examined how farmers in the developed world value and use weather and climate information as a tool to manage their agricultural operations or adapt to changing weather conditions (McCrea et al. 2005; Hu et al. 2006; Tarnoczi and Berkes 2010; Crane et al. 2010; PytlikZillig et al. 2010; Hogan et al. 2010; Furman et al. 2011). However, few studies have specifically explored the role of agricultural advisors in using weather/climate information to help farmers make decisions (but see Buizer et al. 2010).

In the last $30 \mathrm{yr}$, a wide variety of tools have been developed to support agricultural decision making by integrating soil, weather, and crop management with regional and global data to create models that identify and solve problems. Many improvements have occurred in weather forecasting and delivery systems over this time. Moreover, research has been conducted to aid in the development of decision support tools to help farmers and their advisors incorporate weather and climate information into their decision-making framework (Breuer et al. 2008, 2009; Carberry et al. 2002; McCown et al. 2012). However, many of these decision support systems and weather or climate forecasts are not well accepted or fully utilized by farmers (Ash et al. 2007; McCown et al. 2012). In Australia, the Farmers', Advisers' and Researchers' Monitoring, Simulation, Communication, and Performance Evaluation (FARMSCAPE) project (Carberry et al. 2002; McCown et al. 2012) sought to understand why farmers, as well as their public advisors and private consultants, were not more enthusiastic about using and developing more relevant computer-based decision support tools to help adapt to and take advantage of weather variability. The project concluded that private sector consultants were likely good targets for decision support tools because they could be trained to help the agricultural sector apply these tools to decision making. Similarly in the southeastern United States, a highly participatory adaptation-toclimate-variability project (AgroClimate) has highlighted extension agents' interest in considering improved forecasts to aid farmers in the timing and location of planting (Breuer et al. 2008, 2009; Dinon et al. 2012).

However, questions remain around agricultural advisors' willingness to use weather and climate information to help cope with the risk of increasingly variable weather patterns and long-term climate shifts in temperature, precipitation, and seasonality. Improved understanding of agricultural advisors and the ways they utilize climate information is essential to advancing our knowledge of their role as brokers and disseminators of climate information. This study explores if and how various types of advisors in the Corn Belt region incorporate weather/climate information into the advice they give, and their perceptions about the utility of weather/climate information for farm management.

\section{Methods}

Over 2080 technical specialists who advise corn producers in four states in the midwestern United States responded to an electronic survey in the spring of 2012. These four states were purposefully selected to represent the diversity of corn cropping systems in the region, Michigan grows corn in only part of the state and has a rich tradition of other crop production, Indiana and Iowa's landscapes are dominated by a corn/soybean rotation that is primarily rain fed, and Nebraska has a mix of rain-fed and irrigated corn production.

In the majority of cases, advisors were identified from their organization and agency websites. In a few cases, organizations either provided lists of advisors or distributed the survey themselves, so as to protect the confidentiality of their members. A complete list of the types of advisors we contacted in each state and response rates for each category is included in Table 1. A comprehensive survey was developed with input from state climatologists and pretested with advisors. The survey was distributed using web survey software (Qualtrics in Indiana, Nebraska, and Michigan; and SPSS Dimensions in Iowa), allowing personalized e-mails to the majority of recipients. Up to two reminders were sent to recipients, with the overall response rate of $27 \%$. Several people who probably do not advise corn producers were likely included on our mailing lists and will not have responded, making the reportable response rate artificially low. We believe this to be a good response rate for this audience, which has never been surveyed before; however, as with all surveys, there is potential for response bias with respondents more interested in weather and climate information being more likely to complete the survey.

\section{Results and discussion}

On average, the respondents have worked almost 19 years in their role as an advisor to corn producers. For the most part, they provide advice free of charge or as part of other products or services, such as seed corn, 
TABLE 1. Survey population and recruitment. Unless noted otherwise, the e-mail lists were drawn from the organization's web-based lists by a researcher in each state. USDA $=$ U.S. Department of Agriculture.

\begin{tabular}{|c|c|c|c|c|c|c|}
\hline & & Indiana & Iowa & Michigan & Nebraska & Total \\
\hline 1 & Crop advisors/soil scientists & $173 / 610(28 \%)$ & $104 / \sim 350^{\mathrm{b}}(\sim 30 \%)$ & $54 / 213(25 \%)$ & $103 / 439(23 \%)$ & $330 / 1262(26 \%)$ \\
\hline 2 & Agriculture retailers & $4 / 22(19 \%)$ & $9 / \sim 20^{\mathrm{b}}(\sim 45 \%)$ & $11 / 66(17 \%)$ & $66 / 464^{\mathrm{a}}(14 \%)$ & $81 / 552(15 \%)$ \\
\hline 3 & Bankers & $38 /{ }^{b}$ & $63 / \sim 200^{\mathrm{b}}(\sim 32 \%)$ & $6 / 43(14 \%)$ & $173 / 914^{\mathrm{c}}(19 \%)$ & $179 / 957(19 \%)$ \\
\hline 4 & Growers groups & $14 / 57(25 \%)$ & $11 / 29^{\mathrm{a}}(38 \%)$ & $8 / 57(14 \%)$ & $11 / 26(42 \%)$ & $44 / 169(26 \%)$ \\
\hline 5 & $\begin{array}{l}\text { University extension (agriculture } \\
\text { and natural resource agents) }\end{array}$ & $46 / 138(33 \%)$ & $28 / 50(56 \%)$ & $27 / 94(29 \%)$ & $40 / 87(46 \%)$ & $141 / 369(38 \%)$ \\
\hline 6 & USDA Farm Service Agency & $93 / 378(25 \%)$ & $121 / 606(20 \%)$ & $39 / 72(54 \%)$ & $209 / 543(38 \%)$ & $462 / 1599(29 \%)$ \\
\hline 7 & $\begin{array}{l}\text { Natural Resource Conservation } \\
\text { Service }\end{array}$ & $55 / 183(30 \%)$ & $-\mathrm{d}$ & $49 / 174(28 \%)$ & $179 / 286(63 \%)$ & $283 / 643(44 \%)$ \\
\hline 8 & Agricultural cooperatives & $3 / 14(21 \%)$ & $83 / 513(16 \%)$ & $4 / 18(22 \%)$ & - $^{\mathrm{e}}$ & $90 / 545(17 \%)$ \\
\hline 9 & Agricultural lawyers & - e & $-\mathrm{e}^{\mathrm{e}}$ & $0 / 3(0 \%)$ & $36 / 216(17 \%)$ & $36 / 219(16 \%)$ \\
\hline 10 & County weed supervisors & - $^{\mathrm{e}}$ & $27 / 53^{\mathrm{a}}(51 \%)$ & - & $23 / 83(28 \%)$ & $50 / 136(37 \%)$ \\
\hline 11 & Local conservation districts & $53 / 257(21 \%)$ & $137 / 600(23 \%)$ & $33 / 142(23 \%)$ & $34 / 88(39 \%)$ & $257 / 1087(24 \%)$ \\
\hline 12 & State Department of Agriculture & $23 / 34(68 \%)$ & $25 / 56(45 \%)$ & $16 / 28(57 \%)$ & $-\mathrm{e}$ & $64 / 118(54 \%)$ \\
\hline \multirow[t]{2}{*}{13} & $\begin{array}{l}\text { State Department of } \\
\text { Environment/Natural } \\
\text { Resources }\end{array}$ & $16 / 52(31 \%)$ & $50 / 117(43 \%)$ & $4 / 11(36 \%)$ & $-^{\mathrm{e}}$ & $70 / 180(39 \%)$ \\
\hline & Total & $480 / 1745(28 \%)$ & $482 / 2024(24 \%)$ & $251 / 921(27 \%)$ & $874 / 3146(28 \%)$ & $2087 / 7836(27 \%)$ \\
\hline
\end{tabular}

${ }^{a}$ Generic e-mail from researchers was forwarded by organization representative to group members.

${ }^{\mathrm{b}}$ Generic e-mail from researchers was forwarded by organization representative, and the organization did not provide final information on how many members received the survey so a response rate could not be calculated. These responses are not included in the response rate calculation.

${ }^{c}$ E-mail list provided directly to researchers by organization so that a survey could be sent to each member.

${ }^{\mathrm{d}}$ In Iowa this group was combined with the USDA conservation districts.

${ }^{\mathrm{e}}$ E-mail addresses were not available for this group.

bank loans, crop inputs, insurance policies, or equipment. Less than $4 \%$ of the advisors always charge a direct fee for their services and only $8 \%$ sometimes charge a fee. When asked what types of advice they provide to corn producers (with multiple answers allowed), just over $50 \%$ of advisors indicated that they give advice on conservation practices, followed by agronomic (seed dealer, crop input, or other crop management service) advice $(44 \%)$, financial advice $(29 \%)$, and daily management advice $(26 \%)$. Less than $20 \%$ of the respondents checked other types of advice, including marketing, equipment, and full-farm management. Although we inadvertently omitted advising on government and farm bill programs in the survey, 162 people $(8 \%)$ included this option in the "other" category. Overall, these numbers show there is great diversity in the kind of advice provided, including guidance on both agronomic and economic aspects of farming.

\section{a. What types of weather/climate information do advisors currently use?}

To gauge current weather/climate information use, the survey asked: "In general, how much do the following types of weather information influence the advice you give to corn producers?" about seven types of information: historical weather trends, weather data for the past 12 months, current weather conditions, 1-7-day forecasts, 8-14-day outlooks, monthly or seasonal outlooks, and annual or longer-term outlooks. They ranked each of these along a four-point scale ranging from "no influence" to "strong influence." Overall, the results show that advice is primarily influenced by current weather conditions and short-term forecasts. Moreover, the influence/relevance of climate information seems to decline the further its utility is removed from farmers' short-term decisions, with both historical data and longer-term outlooks being used less frequently. This presents both a challenge and an opportunity for developers to show the usability of climate outlooks for long-term management (see Kirchhoff 2010).

Table 2 shows the types of weather- and climaterelated decision support resources advisors are currently using. The survey asked: "Do you use any of the following weather-related decision support resources?" with the response options "Use," "Don't use," and "Not familiar with." The types of resources most commonly used are drought monitor/outlooks (64\%), followed by growing degree-day tools (57\%). Forage dry-down indices 9\%) and farmers' almanacs (18\%) are the least used. Advisors generally report high familiarity with all the resources listed, with forage dry-down indices and satellite data/indices of water or soil nitrogen 
TABLE 2. Use of weather-related decision support resources by advisors.*

\begin{tabular}{|c|c|c|c|}
\hline & Use & $\begin{array}{l}\text { Don't } \\
\text { use }\end{array}$ & $\begin{array}{l}\text { Not familiar } \\
\text { with }\end{array}$ \\
\hline & \multicolumn{3}{|c|}{ Percentage } \\
\hline a. Crop disease forecast $(n=1599)$ & 42 & 39 & 19 \\
\hline b. Insect forecast $(n=1592)$ & 44 & 40 & 17 \\
\hline $\begin{array}{l}\text { c. Evapotranspiration (ET) index } \\
(n=1592)\end{array}$ & 24 & 51 & 26 \\
\hline $\begin{array}{l}\text { d. Growing degree-day tools } \\
(n=1598)\end{array}$ & 57 & 33 & 10 \\
\hline $\begin{array}{l}\text { e. Forage dry-down index } \\
(n=1585)\end{array}$ & 9 & 65 & 27 \\
\hline $\begin{array}{l}\text { f. Drought monitor/outlook } \\
(n=1605)\end{array}$ & 64 & 28 & 8 \\
\hline $\begin{array}{l}\text { g. Satellite data/indices of water or } \\
\text { soil nitrogen status }(n=1590)\end{array}$ & 23 & 50 & 27 \\
\hline h. Farmers' Almanac $(n=1595)$ & 18 & 77 & 5 \\
\hline
\end{tabular}

* Question asked: "Do you use any of the following weatherrelated decision support resources? Note that these resources may be accessible via newsletters, websites, meetings, radio and other sources and they may not have the exact same name listed here."

status mentioned as the options with which they are the least familiar.

\section{b. For what types of decisions can weather/climate information be used?}

We asked advisors to tell us whether they considered weather or climate information when they give advice to corn farmers about a variety of different agricultural decisions. We also asked advisors to tell us when they think corn producers typically make those decisions. For analysis, following Hollinger (2009), we categorized 16 types of decisions into three categories: operational (lead time of days to weeks), tactical (lead time of months), and strategic (lead time of a year or more). Hollinger acknowledges that some decisions, such as tillage practices and crop rotations, belong in more than one category; we followed the lead of the respondents in assigning time categories. For example, advisors identified September-November as the primary time for making decisions about fall tillage, indicating a clear interpretation of this decision as operational. Table 3 shows that, on average, short-term or operational-level advice is most frequently influenced by weather trends and/or forecasts, while longer-term tactical and strategiclevel advice is less frequently influenced. Regardless of the type of advice, $13 \%-19 \%$ of respondents who give advice on a particular topic area stated that although they do not currently give advice based on the weather, they would if they had better information. "Better information" was not defined for the respondents and future work should explore what this would
TABLE 3. Advisors' use of historical weather trends and/or forecasts when giving advice to corn producers.*

\begin{tabular}{|c|c|c|c|}
\hline & $\begin{array}{l}\text { Yes, } \\
\text { I do }\end{array}$ & $\begin{array}{l}\text { No, but I would } \\
\text { if I had better } \\
\text { information }\end{array}$ & $\begin{array}{l}\text { No, } \\
\text { I don't }\end{array}$ \\
\hline & \multicolumn{3}{|c|}{ Percentage } \\
\hline \multicolumn{4}{|c|}{ Operational-Lead time of days to weeks } \\
\hline $\begin{array}{l}\text { Planting or harvest schedule } \\
\qquad(n=814)\end{array}$ & 65 & 14 & 22 \\
\hline $\begin{array}{l}\text { Timing of nitrogen application } \\
\quad(n=914)\end{array}$ & 70 & 15 & 15 \\
\hline $\begin{array}{l}\text { Whether or not to till in fall } \\
\qquad(n=954)\end{array}$ & 55 & 16 & 30 \\
\hline $\begin{array}{l}\text { Integrated pest management } \\
\text { practices }(n=879)\end{array}$ & 61 & 17 & 22 \\
\hline \multicolumn{4}{|c|}{ Tactical_Lead time of months } \\
\hline Seeding rate selection $(n=726)$ & 57 & 15 & 28 \\
\hline Seed purchases $(n=690)$ & 56 & 14 & 30 \\
\hline Fertilizer purchases $(n=744)$ & 45 & 13 & 42 \\
\hline Pesticide purchases $(n=710)$ & 43 & 14 & 43 \\
\hline Propane purchases $(n=356)$ & 24 & 14 & 63 \\
\hline $\begin{array}{l}\text { Purchasing crop insurance } \\
\quad(n=667)\end{array}$ & 53 & 13 & 34 \\
\hline $\begin{array}{l}\text { Fuel purchases for irrigation } \\
\qquad(n=307)\end{array}$ & 25 & 12 & 62 \\
\hline $\begin{array}{l}\text { Crop rotations and field } \\
\text { assignments }(n=896)\end{array}$ & 52 & 15 & 33 \\
\hline Use of cover crops $(n=946)$ & 52 & 19 & 29 \\
\hline \multicolumn{4}{|c|}{ Strategic_Lead time of a year or more } \\
\hline $\begin{array}{l}\text { Investment in irrigation systems } \\
\quad(n=473)\end{array}$ & 46 & 13 & 41 \\
\hline $\begin{array}{l}\text { Investment in agricultural drainage } \\
\text { systems }(n=685)\end{array}$ & 52 & 15 & 34 \\
\hline $\begin{array}{l}\text { Adoption of conservation practices } \\
\text { (not including drainage) } \\
(n=1130)\end{array}$ & 63 & 14 & 24 \\
\hline
\end{tabular}

* Question asked: "When you give advice to corn producers about the following decisions, do you consider historical weather trends and/or forecasts?" (answer options were not presented in the order presented here).

entail as the concept covers a broad range of issues, such as accuracy, mode of delivery, and salience. For a few areas of farm management (i.e., fuel and input purchases), most advisors in these states do not appear to attribute any utility to weather/climate information.

Respondents were asked to check types of farm decisions for which corn producers can use historical weather and/or trend forecasts. Table 4 shows answers ranging from "plan planting" $(82 \%)$ to "plan fuel purchases" (33\%). As with the earlier question, weather/ climate information is perceived as most useful for operational decisions. Only 5\% of respondents stated that "weather forecasts are not useful to corn production" and only $9 \%$ said that "historical weather trends are 
TABLE 4. Advisors' perceptions of usefulness of weather/climate information for corn farmer decisions $(n=1596)$.*

Those who said historical weather and/or trend forecasts can be used (\%)

\begin{tabular}{|c|c|}
\hline \multicolumn{2}{|c|}{ Operational } \\
\hline Plan planting & 82 \\
\hline Plan harvest & 69 \\
\hline Plan tillage timing/strategy & 69 \\
\hline \multicolumn{2}{|c|}{ Tactical } \\
\hline Improve marketing strategies & 53 \\
\hline Better plan input purchases & 50 \\
\hline Plan fuel purchases & 33 \\
\hline Reduce risk of economic losses & 70 \\
\hline Tailor hybrid selection & 69 \\
\hline Increase profitability & 65 \\
\hline Select or modify insurance products & 62 \\
\hline $\begin{array}{l}\text { Allocate field assignments and crop } \\
\text { rotations }\end{array}$ & 58 \\
\hline \multicolumn{2}{|l|}{ Strategic } \\
\hline Improve irrigation planning & 54 \\
\hline $\begin{array}{l}\text { Historical weather trends are not } \\
\text { useful to corn producers }\end{array}$ & 9 \\
\hline $\begin{array}{l}\text { Weather forecasts are not useful to } \\
\text { corn producers }\end{array}$ & 5 \\
\hline
\end{tabular}

not useful to corn production," again suggesting a general openness to using historical weather information and forecasts.

\section{c. Are advisors willing and able to provide advice based on weather/climate information?}

A series of five-point Likert scale questions assessing opinions were included in the survey. Three of these are particularly relevant for this discussion. Over $64 \%$ of advisors agree with the statement that "changing practices to cope with increasing climate variability is important for the long-term success of the farmers I advise," while $28 \%$ are uncertain and $8 \%$ disagree. The term climate variability was not defined, and future work could explore what aspects of a variable climate advisors think is most important for long-term success. There was less certainty around advisors' willingness or confidence in providing advice based on weather and climate information. Only $31 \%$ agree with the statement "I would like to provide advice based on climate forecasts," while $45 \%$ of respondents are uncertain and $24 \%$ of respondents disagree. Similarly, $36 \%$ of respondents agree with the statement "I am confident in my ability to apply weather forecasts and information in my crop related advice," while $41 \%$ of respondents are neutral about the statement and $23 \%$ disagree.
These results show many advisors think that longterm success in farming will be linked to adapting practices for climate variability. Yet their willingness and confidence in providing advice shaped by weather and climate information may still be lacking. Still, with more than $75 \%$ of the advisors not completely unwilling to provide advice based on climatic information, there are indications of an opportunity to inform and educate agricultural advisors about weather and climate information and to develop agricultural decision support tools to guide that advice. It is reasonable to expect that the advisors' confidence will grow as they learn about different weather/climate projections, the relationships among weather/climate information and agricultural decisions, and the array of decision support tools that could be created to guide both short- and long-term agricultural decisions and investments.

\section{Conclusions}

The results from this survey suggest opportunities, as well as challenges, for engaging the advisor community on weather and climate issues and, through them, the corn producers who are making decisions about land management. This study indicates that many advisors are open to incorporating weather/climate information into their advice, and a majority agrees that the farmers they advise will need to adapt to cope with increasing climate variability. However, there are types of information and decisions that advisors do not currently see as having much utility. Increasing advisors' understanding of the usefulness of certain types of weather and climate information, such as 8-14-day outlooks and monthly/seasonal outlooks, and the potential applications of weather/climate information to tactical and strategic decisions, should be high on the agenda of climate information developers. This echoes the recommendations of Hayman et al. (2007), who suggest identifying when, where, and what decisions may benefit most from use of seasonal climate forecasts.

It may be helpful for tool developers to expand upon commonly used weather decision support resources, such as drought monitor/outlooks and growing degreeday tools, and to focus on developing support tools for operational decisions that advisors already think benefit from weather and climate information. These types of "low hanging fruit" could be used to make more advisors comfortable with weather and climate information before expanding to decisions for which they have not traditionally used weather and climate information. In addition, enhancing advisors' understanding of the utility of different types of climate information should be a priority for climate forecast and tool developers, 
perhaps using regionally specific crop simulation models that allow for the testing of different management decisions under a variety of past and future climatic conditions (Hansen 2002). Capacity-building efforts to increase advisor confidence and knowledge appear to be worthy investments toward the goals of increasing use of weather/climate information in farm management decisions and ensuring adaptability and profitability of agricultural cropping systems into the future.

Acknowledgments. This project was supported by Agriculture and Food Research Initiative Competitive Grant 2011-68002-30220 from the USDA National Institute of Food and Agriculture. We thank the entire Useful to Usable (U2U) team for their insights into both the survey and analysis.

\section{REFERENCES}

Ash, A., P. McIntosh, B. Cullen, P. Carberry, and M. S. Smith, 2007: Constraints and opportunities in applying seasonal climate forecasts in agriculture. Aust. J. Agric. Res., 58, 952-965.

Breuer, N. E., V. E. Cabrera, K. T. Ingram, K. Broad, and P. Hildebrand, 2008: AgClimate: A case study in participatory decision support system development. Climatic Change, 87, 385-403, doi:10.1007/s10584-007-9323-7.

_ , C. W. Fraisse, and P. E. Hildebrand, 2009: Molding the pipeline into a loop: The participatory process of developing AgroClimate, a decision support system for climate risk reduction in agriculture. J. Serv. Climatol., 3. [Available online at www.journalofserviceclimatology.org.]

Buizer, J., K. Jacobs, and D. Cash, 2010: Making short-term climate forecasts useful: Linking science and action. Proc. Natl. Acad. Sci. USA, doi:10.1073/pnas.0900518107, in press.

Carberry, P. S., and Coauthors, 2002: The FARMSCAPE approach to decision support: Farmers', advisers', researchers' monitoring, simulation, communication and performance evaluation. Agric. Syst., 74, 141-177, doi:10.1016/S0308-521X(02)00025-2.

Crane, T. A., C. Roncoli, J. Paz, N. Breuer, K. Broad, K. T. Ingram, and G. Hoogenboom, 2010: Forecast skill and farmers' skills: Seasonal climate forecasts and agricultural risk management in the southeastern United States. Wea. Climate Soc., 2, 44-59.

Dinon, H., N. Breuer, R. Boyles, and G. Wilkerson, 2012: North Carolina extension agent awareness of and interest in climate information for agriculture. Southeast Climate Consortium Tech. Rep. 12-003, 44 pp. [Available online at http://www. seclimate.org/pdfpubs/SECCsurveyReportFinal.pdf.]

Furman, C., C. Roncoli, T. Crane, and G. Hoogenboom, 2011: Beyond the "fit": Introducing climate forecasts among organic farmers in Georgia (United States). Climatic Change, 109, 791-799, doi:10.1007/s10584-011-0238-y.

Hansen, J. W., 2002: Realizing the potential benefits of climate prediction to agriculture: Issues, approaches, challenges. Agric. Syst., 74, 309-330.

Hayman, P., J. Crean, J. Mullen, and K. Parton, 2007: How do probabilistic seasonal climate forecasts compare with other innovations that Australian farmers are encouraged to adopt? Aust. J. Agric. Res., 58, 975-984.

Hogan, A., H. L. Berry, S. Peng Ng, and A. Bode, 2010: Decisions made by farmers that relate to climate change. Australian Government Rural Industries Research and Development Corp. Rep. 10-208, 78 pp. [Available online at https://rirdc. infoservices.com.au/items/10-208.]

Hollinger, S. E., 2009: Meteorological forecasting for agricultural production. Systems Analysis and Modeling in Food and Agriculture, K. C. Ting, D. H. Fleisher, and L. F. Rodriguez, Eds., Food and Agricultural Sciences, Engineering and Technology Resources Series, EOLSS Publishers, 397-409.

$\mathrm{Hu}, \mathrm{Q}$., and Coauthors, 2006: Understanding farmers' forecast use from their beliefs, values, social norms, and perceived obstacles. J. Appl. Meteor. Climatol., 45, 1190-1201.

Karl, T. R., J. M. Melillo, and T. C. Peterson, Eds., 2009: Global climate change impacts in the United States. Cambridge University Press, 192 pp. [Available online at http://www. globalchange.gov/publications/reports/scientific-assessments/ us-impacts.]

Kirchhoff, C. J., 2010: Integrating science and policy: Climate change assessments and water resources management. Ph.D. dissertation, University of Michigan, $280 \mathrm{pp}$.

McCown, R. L., P. S. Carberry, N. P. Dalgliesh, M. A. Foale, and Z. Hochman, 2012: Farmers use intuition to reinvent analytic decision support for managing seasonal climatic variability. Agric. Syst., 106, 33-45, doi:10.1016/j.agsy.2011.10.005.

McCrea, R., L. Dalgleish, and W. Coventry, 2005: Encouraging use of seasonal climate forecasts by farmers. Int. J. Climatol., 25, 1127-1137, doi:10.1002/joc.1164.

PytlikZillig, L. M., Q. Hu, K. G. Hubbard, G. D. Lynne, and R. H. Bruning, 2010: Improving farmers' perception and use of climate predictions in farming decisions: A transition model. J. Appl. Meteor. Climatol., 49, 1333-1340.

Stone, R. C., and H. Meinke, 2006: Weather, climate, and farmers: An overview. Meteor. Appl., 13 (Suppl.), 7-20.

Tarnoczi, T., and F. Berkes, 2010: Sources of information for farmers' adaptation practices in Canada's prairie agro-ecosystem. Climatic Change, 98, 299-305, doi:10.1007/s10584-009-9762-4.

USDA FAS, cited 2012: Production, supply and distribution online database. [Available online at http://www.fas.usda.gov/ psdonline/.]

USDA NASS, cited 2011: Crop production annual summary for 2010. [Available online at http://usda.mannlib.cornell.edu/ MannUsda/viewDocumentInfo.do?documentID=1047.] 